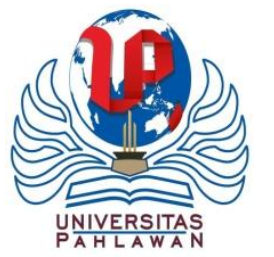

Jurnal Basicedu Volume 1 Nomor 1 Tahun 2017 Halaman 21-30

JURNAL BASICEDU

Research \& Learning in Elementary Education

http:// stkiptam.ac.id/indeks.php/basicedu

\title{
PENGGUNAAN MEDIA AUDIO VISUAL UNTUK MENINGKATKAN HASIL BELAJAR PENDIDIKAN KEWARGANEGARAAN SISWA KELAS IV SD NEGERI 016 BANGKINANG KOTA
}

\author{
Rizki Ananda ${ }^{1}$ \\ ${ }^{1}$ Dosen Prodi PGSD Universitas Pahlawan Tuanku Tambusai \\ e-mail : rizkiananda.mhs.upi@gmail.com
}

\begin{abstract}
Abstrak
Based on observations, indicating civic learning still conventionally implemented where teachers are still using instructional media were confined to the textbook. This causes make the students is not actice in the learning process and learning results obtained are low. Focused on the problem, this research aims to improve the planning, implementation and assessment of learning civics by using audio-visual media. This classroom action research using qualitative and quantitative approaches. In practice, this research consisted of two cycles was taken collaboratively with classroom teachers. Each cycle consists of planning, implementing measures are accompanied observations and reflections on each cycle. The research was conducted in the second semester of the academic year 2015/2016 in 016 Bangkinang City Elementary School with the research subjects were all students in fourth grade. The research data was collected through observation, interviews, field notes, documentation and test. The results of data analysis showed that the use of audio-visual media can improve student learning outcomes in learning in fourth grade Civics 016 Bangkinang City State. It is seen from (1) The results of student learning in the cognitive an increase of the average value of 7.1 in the first cycle to 8.0 in the second cycle, (2) the affective domain increased from an average value of 7.8 on I cycle to 8.5 in the second cycle, and (3) on psychomotor increased from an average value of 6.4 in the first cycle to 7.9 in the second cycle. Seeing the results of this study, the class action research in the use of audio-visual media in Civics learning needs to be applied and developed in order to improve the quality of education in the future.
\end{abstract}

Keywords: Civic education learning, audio-visual media, and elementary school students 


\section{PENDAHULUAN}

\section{Latar Belakang}

Pendidikan Kewarganegaraan (PKn) merupakan suatu wahana untuk mengembangkan dan melestarikan nilai luhur dan moral yang berakar pada budaya Bangsa Indonesia yang diharapkan dapat diwujudkan dalam bentuk perilaku kehidupan sehari-hari. Depdiknas (2006:271) menjelaskan bahwa "mata pelajaran PKn di Sekolah Dasar (SD) merupakan mata pelajaran yang memfokuskan pada pembentukan warga negara yang memahami dan mampu melaksanakan hak-hak dan kewajibannya untuk menjadi warga negara Indonesia yang cerdas, terampil, dan berkarakter yang diamanatkan oleh Pancasila dan UUD 1945".

Senada dengan pernyataan di atas, Wahab (1997:3) mengemukakan bahwa "PKn di SD merupakan program pendidikan yang berlandaskan nilai-nilai Pancasila sebagai wahana untuk mengembangkan dan melestrikan nilai-nilai luhur dan moral yang berakar pada budaya Bangsa Indonesia yang diharapkan dapat menjadi jati diri yang diwujudkan dalam bentuk perilaku dalam kehidupan sehari-hari dari seluruh warga Negara Indonesia”.

Berdasarkan pendapat para ahli di atas dapat disimpulkan bahwa PKn di SD merupakan program pendidikan yang bertolak dari dan memusatkan perhatian pada konsep, nilai, moral, norma, dan perilaku sesuai Pancasila dan UUD 1945 serta hak dan kewajiban sebagai warga negara.

Ternyata untuk mencapai tujuan dan harapan di atas tidak mudah. Terdapat beberapa hambatan dalam pembelajaran PKn. Realitas di lapangan menunjukkan bahwa pembelajaran PKn di beberapa Sekolah Dasar (SD) dalam upaya membentuk kepribadian dan moral siswa dinilai belum optimal. Rendahnya kreatifitas guru dalam pengelolaan proses pembelajaran dan padatnya muatan kurikulum diduga menjadi faktor penyebabnya. Pengelolaan proses pembelajaran yang kurang efektif akan menyebabkan kurang bermaknanya konsepkonsep yang diajarkan. Selain itu, selama ini
PKn masih dianggap sebagai pelajaran yang mementingkan hafalan semata, bukan untuk berpikir kreatif, kritis, dan analitis.

Berdasarkan hasil observasi serta wawancara dengan guru kelas IV (tanggal 27 Juni 2016) di SDN 016 Bangkinang Kota, menunjukkan bahwa hasil belajar yang diperoleh siswa dalam pembelajaran PKn hanya terbatas pada penguasaan pengetahuan atau hafalan konsep semata. Dengan kata lain, hasil belajar yang dituntut dari siswa hanya dari ranah kognitif saja. Target pencapaian hasil belajar siswa hanya sebatas untuk mengikuti ujian semester. Sementara, pencapaian hasil belajar untuk ranah afektif dan psikomotor terabaikan.

Sementara itu data rekapitulasi nilai akhir murni semester II kelas IV tahun pelajaran 2015/2016 yang peneliti peroleh dari SDN 016 Bangkinang Kota menunjukkan bahwa nilai atau hasil belajar siswa pada mata pelajaran PKn adalah nilai terendah jika dibandingkan dengan mata pelajaran pokok lainnya. Data ini dapat dilihat pada tabel di bawah ini:

Tabel 1.1

\section{Rekapitulasi Nilai Akhir Murni}

\begin{tabular}{|l|c|c|c|c|c|}
\hline $\begin{array}{c}\text { Mata } \\
\text { Pelajaran }\end{array}$ & $\begin{array}{c}\text { Ag } \\
\text { am } \\
\mathbf{a}\end{array}$ & PKn & B.I & $\begin{array}{c}\text { Mt } \\
\mathbf{k}\end{array}$ & IPA \\
\hline $\begin{array}{l}\text { Jumlah } \\
\text { Nilai }\end{array}$ & $\begin{array}{c}22 \\
7\end{array}$ & 170 & $\begin{array}{c}24 \\
6\end{array}$ & 251 & 264 \\
\hline $\begin{array}{l}\text { Rata-rata } \\
\text { Nilai }\end{array}$ & $\begin{array}{c}5,8 \\
0\end{array}$ & 4,40 & $\begin{array}{c}6,2 \\
5\end{array}$ & $\begin{array}{c}6,3 \\
0\end{array}$ & 6,60 \\
\hline $\begin{array}{l}\text { Nilai } \\
\text { Tertinggi }\end{array}$ & $\begin{array}{c}8,0 \\
0\end{array}$ & 7,00 & $\begin{array}{c}8,0 \\
0\end{array}$ & $\begin{array}{c}10, \\
0\end{array}$ & 9,00 \\
\hline $\begin{array}{l}\text { Nilai } \\
\text { Terendah }\end{array}$ & $\begin{array}{c}4,0 \\
0\end{array}$ & 3,00 & $\begin{array}{c}4,0 \\
0\end{array}$ & $\begin{array}{c}5,0 \\
0\end{array}$ & 5,00 \\
\hline $\begin{array}{l}\text { Daya } \\
\text { Serap }\end{array}$ & $\begin{array}{c}58 \\
\%\end{array}$ & $44 \%$ & $\begin{array}{c}62 \\
\%\end{array}$ & $\begin{array}{c}63 \\
\%\end{array}$ & $66 \%$ \\
\hline $\begin{array}{l}\text { Jumlah } \\
\text { Siswa }\end{array}$ & \multicolumn{5}{|c|}{40 orang } \\
\hline
\end{tabular}

(Sumber Data: Bagian Personalia SDN 016 Bangkinang Kota)

Berdasarkan data bagian personalia yang peneliti peroleh dari SDN 016 Bangkinang 
Kota menunjukkan bahwa dengan jumlah siswa 40 orang, yang terdiri dari 23 orang siswa laki-laki dan 17 orang siswa perempuan, hanya 7 orang yang memperoleh nilai hasil belajar PKn di atas 5,00, selainnya memperoleh nilai 5,00 ke bawah. Nilai tertinggi yang diperoleh adalah 7,00 dan nilai terendah 3,00 , dengan nilai rata-rata kelas adalah 4,40 dan daya serap siswa hanya mencapai $44 \%$ yang merupakan rata-rata kelas dan daya serap terendah jika dibandingkan dengan mata pelajaran pokok lainnya.

Data lapangan yang telah peneliti peroleh dari wawancara dan observasi di atas, menunjukkan bahwa kurangnya keaktifan, kreatifitas dan partisipasi siswadalam mengikuti proses pembelajaran pada mata pelajaran PKn di kelas IV tersebut. Siswa jarang bertanya tentang materi pembelajaran yang telah diberikan guru. Sementara, apabila guru mengajukan pertanyaan seputar materi pembelajaran yang telah disampaikan, sebagian besar siswa tidak mampu menjawab pertanyaan yang diajukan guru. Di samping itu, siswa cepat merasa jenuh dan tidak konsentrasi dalam mengikuti proses pembelajaran. Siswa sering meribut dan bercanda dengan teman sekelasnya selama proses pembelajaran berlangsung.

Fenomena di atas menunjukkan bahwa permasalahan yang terjadi disebabkan oleh metode pembelajaran yang dipakai oleh guru lebih cenderung menggunakan metode ceramah dan tanya jawab. Guru kurang memberikan kesempatan kepada siswauntuk mengembangkan kemampuan berfikir holistik, kreatif, objektif dan logis. Faktor lain yang sangat mempengaruhi adalah penggunaan media pembelajaran yang belum maksimal serta kejenuhan siswaterhadap media pembelajaran yang masih monoton dipergunakan guru dalam proses pembelajaran. Dilihat dalam penggunaannya di SDN 016 Bangkinang Kota, khususnya pada mata pelajaran PKn di kelas IV, guru belum memanfaatkan media pembelajaran yang bervariasi dalam proses pembelajaran. Guru hanya mempergunakan media papan tulis dan media gambar pada buku teks dalam menyampaikan materi pembelajaran. Guru jarang sekali mempergunakan media yang mampu memancing kreatifitas dan partisipasi siswa. Kondisi inilah yang menyebabkan rendahnya minat belajar siswa sehingga berdampak pada hasil belajar yang rendah dan prestasi yang monoton.

Bertitik tolak pada kenyataan dan fenomena di atas, peneliti tergerak untuk mengatasi permasalahan tersebut dengan penggunaan media audio visual ini pada pembelajaran PKn di SD. Arsyad (2006:3) menyatakan bahwa media audio visual adalah suatu alat yang mengandung pesan dalam bentuk auditif dan visualitatif (dapat didengar dan dilihat) dan dapat merangsang pikiran, perasaan, perhatian, dan kemauan siswauntuk belajar. Media audio visual seperti film atau video akan memudahkan siswa di SD dalam menyerap materi pelajaran PKn yang diberikan oleh guru. Siswa lebih termotivasi jika pelajaran yang diberikan membawa siswake dunia nyata dan konkrit sesuai dengan perkembangan kematangan siswa usia sekolah dasar. Senada dengan hal tersebut, Piaget (dalam Karim dkk, 1997:20) menjelaskan bahwa pada saat seorang anak berusia 7-12 tahun, mereka mengembangkan konsep dengan benda-benda konkrit untuk menyelidiki hubungan dan model-model media abstrak (tahap operasional konkrit). Dimana pada tahap ini, siswa harus melihat atau mengalami sendiri hal tersebut agar siswa dapat memahami pelajaran atau menjadi keterampilan dan pegangan bagi siswa di masa yang akan datang.

Dengan pemanfaatan media audio visual khususnya film dan video, siswa dapat langsung melihat dan mendengarkan suara sehingga proses pembelajaran lebih bermakna. Selain dapat membantu guru dalam menjelaskan materi pembelajaran diharapkan juga siswa dapat lebih dipahami materi pembelajaran PKn sehingga berimplikasi pada peningkatan hasil belajar siswa.

\section{Tujuan Penelitian}

Secara umum penelitian ini bertujuan untuk mendapatkan gambaran tentang 
penggunaan media audio visual untuk meningkatkan hasil belajar siswa dalam pembelajaran PKn di kelas IV SDN 016 Bangkinang Kota. Secara khusus penelitian ini bertujuan untuk mendeskripsikan:

1. Rancangan pembelajaran dengan menggunakan media audio visual dalam pembelajaran PKn di kelas IV SDN 016 Bangkinang Kota.

2. Pelaksanaan pembelajaran dengan menggunakan media audio visual dalam pembelajaran PKn di kelas IV SDN 016 Bangkinang Kota.

3. Hasil belajar IPS PKn di kelas IV SDN 016 Bangkinang Kota setelah menggunakan media audio visual.

\section{TINJAUAN TEORI}

\section{Definisi Pendidikan Kewarganegaraan}

Secara epistemologis, Pendidikan Kewarganegaraan dikembangkan dalam tradisi citizenship education yang tujuannya sesuai dengan tujuan nasional masing-masing negara. Namun secara umum Pendidikan Kewarganegaraan (PKn) atau Civic Education adalah program pendidikan/pembelajaran yang secara programatik prosedural berupaya memanusiakan (humanizing) dan membudayakan (civilizing) serta memberdayakan (empowering) manusia dalam hal ini siswa (diri dan kehidupannya) menjadi warga negara yang baik sebagaimana tuntutan keharusan/ yuridis konstitusional bangsa/ negara yang bersangkutan (Djahiri, 2006: 9). Demikian juga National Council for the Social Studies/ NCSS (dalam Somantri, 2001:294) mendefinisikan Civic Education dengan rumusan sebagai berikut :

Civic Education is a process comprising all the positive influences which are intended to shape a citizen's view to his role in society. It comes partly from formal schooling, partly from parental influence, through Civic Education our youth are helped to gain an understanding of our national ideals, to common good, the process of self government.

Pada definisi tersebut, pengertian civic education lebih dipertegas lagi karena bahannya meliputi pengaruh positif dari pendidikan di sekolah dan pendidikan di luar kelas/sekolah. Unsur-unsur itu harus dipertimbangkan dalam menyusun civic education yang diharapkan akan membantu para siswa dalam memahami dan mengapresiasikan cita-cita nasional, membuat keputusan yang cerdas, dalam berbagai masalah pribadi, masyarakat dan negara.

Menurut Cogan (1999: 4) "Pendidikan Kewarganegaraan adalah suatu mata pelajaran dasar di sekolah yang dirancang untuk mempersiapkan warga Negara muda, agar kelak setelah dewasa dapat berperan aktif dalam masyarakatnya".

Sementara itu, dalam penjelasan pasal 37 UU Sisdiknas No. 20 Tahun 2003 disebutkan bahwa "Pendidikan Kewarganegaraan dimaksudkan untuk membentuk siswa menjadi manusia yang memiliki rasa kebangsaan dan cinta tanah air". Mulyasana (2006: 166) menyatakan bahwa:

PKn diarahkan pada upaya pemberdayaan siswa menjadi manusia yang bermartabat, mampu bersaing dan unggul dalam berbagai hal dijamannya, serta dapat memberikan manfaat yang sebesar-besarnya bagi kehidupan di lingkungannya. Dalam posisi ini PKn diarahkan pada proses pembebasan siswa dari ketidakbenaran, ketidakadilan, ketidakjujuran, dan pembebasan siswa dari kemerdekaan mengekspresikan hati dan keimanan.

Berdasarkan beberapa pendapat di atas dapat disimpulkan bahwa hakikat Pendidikan Kewarganegaraan adalah suatu upaya untuk menciptakan warga negara yang baik (to be good citizenship). Adapun ciri-ciri warga negara yang baik yang akan dikembangkan dalam Pendidikan Kewarganegaraan adalah tumbuhnya wawasan dan kesadaran bernegara serta membentuk sikap dan perilaku yang cinta tanah air yang bersendikan kebudayaan bangsa. Di samping itu juga bagaimana mengupayakan kesadaran siswa akan hak dan kewajibannya, berpartisipasi secara aktif dan bertanggung jawab, serta bertindak secara cerdas dalam kegiatan bermasyarakat, berbangsa, dan bernegara. Serta untuk mengasah kemampuan dan keterampilan siswa 
sebagai warga negara dalam mengambil prakarsa dan atau turut serta dalam pemecahan masalah sosial-kultural kewarganegaraan di lingkungannya.

\section{Media Film dan Video dalam Pembelajaran PKn di SD}

Penggunaan media audio visual seperti film dan video masih jarang dipakai oleh para guru dalam proses pembelajaran PKn di SD. Guru kebanyakan masih mempergunakan media konvensional (seperti papan tulis dan media gambar sederhana yang juga masih jarang dipergunakan dalam proses pembelajaran). Penggunaan media (terutama media audio visual) dalam pembelajaran PKn di SD merupakan hal yang sangat penting. Penggunaan media pembelajaran sangat membantu peserta didik dalam mengikuti proses pembelajaran, lebih lagi jika peserta didik dilibatkan langsung dalam penggunaan dan pemanfaatan media yang ada. Media audio visual seperti $C D$ pembelajaran (film/video) akan memudahkan peserta didik dalam menyerap materi pelajaran yang diberikan oleh guru.

Sesuai dengan perkembangan zaman pada saat sekarang ini yang ditandai dengan kemajuan di bidang ilmu pengetahuan, teknologi, komunikasi dan informasi, peserta didik lebih senang dengan materi yang disajikan melalui media yang aplikatif dan realistis. Peserta didik lebih termotivasi jika pelajaran yang diberikan membawa peserta didik ke dunia nyata dan konkrit sesuai dengan perkembangan kematangan peserta didik usia sekolah dasar.

Menurut Wibawa dan Farida (1992:75) media audio visual (film/video) dapat berfungsi untuk: 1) Membuat konkrit konsep abstrak, 2) membawa obyek yang berbahaya/sukar didapat di lingkungan belajar, 3) menampilkan obyek yang terlalu besar, 4) menampilkan obyek yang tidak dapat diamati dengan mata telanjang, 5) memperlihatkan gerakan yang terlalu cepat, 6) memungkinkan peserta didik untuk berinteraksi secara langsung dengan lingkungan, 7) memungkinkan pengamatan/persepsi belajar peserta didik, dan 8) membangkitkan motivasi belajar peserta didik.

Penggunaan media (terutama media audio visual) sangat berpengaruh sekali terhadap keberhasilan peserta didik dalam mencapai tujuan pembelajaran PKn disamping dapat memotivasi peserta didik dalam mengikuti proses pembelajaran. Tanpa adanya media yang dipergunakan guru dalam menyampaikan materi pembelajaran akan membuat peserta didik cepat merasa bosan dalam mengikuti proses pembelajaran. Terutama untuk materi PKn yang menuntut hasil belajar berupa suatu sikap dari peserta didik. Tanpa adanya contoh sikap yang dapat dilihat atau diamati langsung oleh peserta didik dari sikap yang dituntut, maka peserta didik akan kesulitan untuk memenuhi tuntutan materi tersebut. Hal ini akan berakibat terhadap ketidaktercapaiannya tujuan pembelajaran yang telah diprogramkan. Contoh sikap yang diharapkan akan lebih efektif bagi siswa usia sekolah dasar bila disajikan dengan media audio visual. Peserta didik akan lebih tertarik serta lebih mudah dan lebih cepat menangkap pesan yang disampaikan melalui media audio visual tersebut.

\section{Hasil Belajar}

Hasil belajar merupakan tolak ukur untuk melihat keberhasilan siswa dalam menguasaai materi pelajaran yang disampaikan selama proses pembelajaran. Menurut Oemar (2008:20) "Hasil belajar adalah tingkah laku yang timbul, misalnya dari tidak tahu menjadi tahu, timbulnya pertanyaan baru, perubahan dalam setiap kebiasaan keterampilan, kesanggupan menghargai, perkembangan sifat sosial, emosial, dan pertumbuhan jasmani”. Sedangkan menurut Sumiati dan Asra (2007:38) hasil belajar adalah "perubahan perilaku". Perilaku itu mencakup pengetahuan pemahaman, ketrampilan, sikap, kemampuan berpikir, penghargaan terhadap suatu permasalahan yang sedang dihadapi. 
Selanjutnya Purwanto (2006:16) menjelaskan hasil belajar siswa dapat ditinjau dari beberapa hasil kognitif yaitu kemampuan siswa dalam pengetahuan (ingatan), pemahaman, penerapan (aplikasi), analisis, sintesis, dan evaluasi.

Berdasarkan pendapat yang telah dipaparkan, hasil belajar dapat dilihat dari kemampuan peserta dalam mengingat pelajaran yang telah disampaikan selama proses pembelajaran dan bagaimana siswa tersebut bisa menerapkannya serta mampu memecahkan masalah yang timbul sesuai dengan apa yang telah dipelajarinya. Dalam KTSP hasil belajar yang dituntut bukan kognitif saja tetapi mencakup tiga ranah yaitu kognitif, afektif, dan psikomotor.

\section{METODOLOGI PENELITIAN}

Pendekatan yang digunakan dalam penelitian ini adalah pendekatan kualitatif. Pendekatan kualitatif ini berkenaan dengan perbaikan atau peningkatan proses pembelajaran pada suatu kelas. Pendekatan kualitatif digunakan karena prosedur penelitian yang menghasilkan data deskriptif berupa kata-kata tertulis atau lisan serta perilaku yang diamati dari orang-orang atau sumber informasi. Sedangkan untuk melihat keberhasilan proses pembelajaran dengan pendekatan kualitatif didukung oleh data kuantitatif. Jenis penelitian yang dilaksanakan adalah Penelitian Tindakan Kelas (Classroom Action Research).

Menurut Arikunto, dkk (2007:58) "Penelitian Tindakan Kelas (PTK) adalah penelitian tindakan (action research) yang dilakukan dengan tujuan memperbaiki mutu pratik pembelajaran di kelasnya". Pendapat ini senada dengan Wardhani, dkk (2007:1.4) "Penelitian tindakan kelas adalah penelitian yang dilakukan oleh guru di dalam kelasnya sendiri melalui refleksi diri, dengan tujuan untuk memperbaiki kinerjanya sebagai guru, sehingga hasil belajar siswa menjadi meningkat".

Mengingat dalam suatu penelitian tindakan kelas peneliti perlu dibantu oleh pendamping sebagai rekan diskusi bagi peneliti, maka dalam hal ini peneliti meminta bantuan guru kelas sebagai pengamat dalam penelitian, mulai dari perencanaan tindakan, pelaksanaan tindakan, observasi, refleksi, dan revisi selama peneliti melakukan penelitian di SDN 016 Bangkinang Kota. Penelitian tindakan kelas ini dilaksanakan melalui tahaptahap yang umumnya dilaksanakan dalam suatu penelitian tindakan kelas. Tahap-tahap tersebut biasa disebut dengan siklus, dimana setiap siklusnya meliputi perencanaan, pelaksanaan tindakan, observasi, evaluasi, dan refleksi. Tahap-tahap penelitian tindakan kelas yang bersifat spiral tersebut digambarkan oleh Hopkins sebagai berikut.

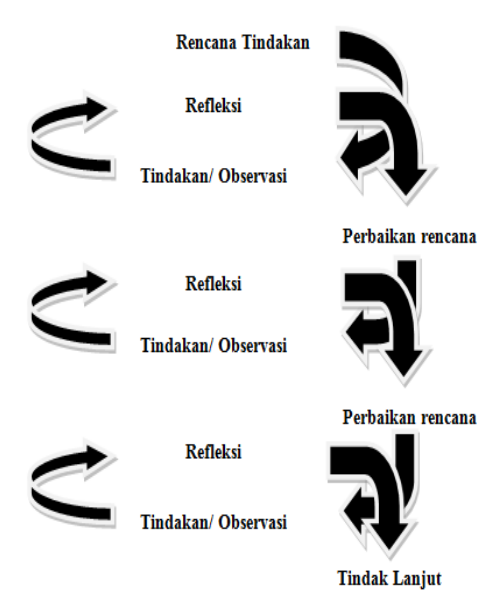

Gambar 1.1

Spiral Penelitian Tindakan Kelas Hopkins (Wiriaatmadja 2008: 66)

Kegiatan penelitian dilaksanakan berdasarkan perencanaan tindakan yang telah ditetapkan, yaitu melaksanakan pembelajaran sesuai rencana pembelajaran yang telah dibuat. Fokus tindakan adalah penggunaan media audio visual untuk meningkatkan pembelajaran PKn. Pada tahap pelaksanaan tindakan ini, proses pembelajaran dilaksanakan dengan menjalankan skenario pembelajaran yang telah dirancang dan terdapat dalam RPP.

\section{HASIL DAN PEMBAHASAN}

Berdasarkan tindakan yang telah dilaksanakan pada siklus I dan II dengan menggunakan media audio visual untuk 
meningkatkan pembelajaran PKn siswa kelas IV SDN 016 Bangkinang Kota dapat dijelaskan hasil penelitian sebagai berikut:

\section{Perencanaan Pembelajaran PKn dengan Menggunakan Media Audio Visual}

Rancangan pembelajaran PKn kelas IV

SD untuk materi "Menyikapi pengaruh globalisasi" pada siklus I dan II secara umum hampir sama, bedanya hanya terletak pada:

1. Pengembangan materi pembelajaran yang disesuaikan dengan tujuan pembelajaran

2. Topik yang dibicarakan dalam naskah bermain peran pada siklus II dibedakan dari siklus I, tetapi masih berkaitan dengan materi pembelajaran

3. Pengembangan butir soal penilaian/evaluasi tes akhir.

\section{Pelaksanaan Pembelajaran PKn dengan Menggunakan Media Audio Visual}

Pelaksanaan pembelajaran pada siklus I dan II ini juga sama bedanya hanya teletak pada penyajian media film dokumenter saja. Langkah-langkah pembelajaran yang dilakukan pada siklus II merupakan perbaikan dari hasil refleksi langkah-langkah pembelajaran yang telah dilaksanakan pada siklus I. Tahapan atau langkah-langkah dalam pelaksanaan pembelajaran masih tetap dibagi tiga tahap, yaitu 1) Tahap persiapan, 2) tahap pelaksanaan (penyajian) dan 3) tahap tindak lanjut.

Penyajian atau pemutaran media film dokumenter dilakukan sekaligus mulai dari awal sampai akhir film/video. Tidak ada jeda atau pemenggalan dalam penyajian film/video dokumenter. Hal ini bertujuan untuk meningkatkan daya ingat siswa terhadap pengamatan yang dilakukannya terhadap media pembelajaran yang telah disajikan guru. Setelah diberi kesempatan pada siswa untuk mengamati film dokumenter sambil mencatat materi yang penting dari film yang diamati, kemudian ditambahkan dengan penjelasan dan pengarahan dari guru, maka hal ini dapat menambah pengalaman dan pengetahuan peserta didik tentang materi pembelajaran. Sehingga di masa mendatang, peserta didik dapat menggunakan pengetahuan tersebut dalam kehidupan mereka.

Perbaikan yang dilakukan juga terlihat pada saat guru meminta siswa mengamati film sambil mencatat materi yang penting dengan lebih tegas, guru juga menambah penguatan agar peserta didik bersedia saat diminta menceritakan film dokumenter secara singkat ataupun melaporkan hasil diskusi ke depan kelas. Selain itu, guru juga menjelaskan lagi lebih rinci perintah yang ada di LKS, kemudian memuji mereka karena menyelesaikan pengisian LKS, karena hal ini dapat menambah semangat belajar peserta didik, seperti yang dikemukakan Dimyati dan Mudjiono (2006:85) bahwa "upaya untuk menumbuhkan dan memicu semangat belajar peserta didik dapat diberikan dengan pujian dan hadiah, hal ini juga dapat digunakan untuk mengobarkan semangat belajar".

\section{Hasil Belajar PKn dengan Menggunakan Media Audio Visual}

Berdasarkan analisis data pengamatan hasil penelitian siklus I, keberhasilan tindakan siklus I untuk hasil belajar ranah kognitif pada tes akhir belum mencapai ketuntasan karena dari 30 peserta didik, 11 orang belum mencapai nilai 6 (nilai standar ketuntasan minimum yang ditetapkan sekolah) dan 19 orang sudah memperoleh nilai 6 atau lebih. Ketuntasan belajar ranah kognitif pada siklus I hanya mencapai $63 \%$ atau kurang dari75\% dengan rata-rata nilai 7,1 . Hal ini juga terjadi pada hasil belajar ranah psikomotor. Dari 30 peserta didik, 15 orang belum mencapai nilai 6 , sementara 15 orang lagi sudah memperoleh nilai 6 atau lebih. Jadi, ketuntasan belajarnya hanya $50 \%$ atau kurang dari $75 \%$ dengan ratarata nilai 6,4. Tetapi berbeda dengan hasil belajar pada ranah afektif yang sudah mencapai ketuntasan. Dari 30 peserta didik, 3 orang belum mencapai nilai 6 , sementara 27 orang lagi sudah memperoleh nilai 6 atau lebih. Jadi, ketuntasan belajarnya hanya $90 \%$ atau di atas $75 \%$ dengan rata-rata nilai 7,8.

Sementara berdasarkan analisis data pengamatan hasil penelitian siklus II, keberhasilan tindakan siklus II untuk hasil 
belajar ranah kognitif pada tes akhir sudah mencapai ketuntasan karena dari 30 peserta didik, hanya 4 orang yang belum mencapai nilai 6 (nilai standar ketuntasan minimum yang ditetapkan sekolah) dan 26 orang sudah memperoleh nilai 6 atau lebih. Ketuntasan belajar ranah kognitif pada siklus I sudah mencapai $86,7 \%$ atau di atas $75 \%$ dan dapat dinyatakan tuntas dengan rata-rata nilai 8,0 . Peningkatan hasil belajar juga terjadi pada ranah afektif. Dari 30 peserta didik, hanya 1 yang orang belum mencapai nilai 6 , sementara 29 orang lagi sudah memperoleh nilai 6 atau lebih. Jadi, ketuntasan belajarnya sudah mencapai $97 \%$ atau di atas $75 \%$ dengan ratarata nilai 8,5. Hasil belajar untuk ranah psikomotor juga sudah mencapai ketuntasan. Dari 30 peserta didik, 6 orang belum mencapai nilai 6 , sementara 24 orang lagi sudah memperoleh nilai 6 atau lebih. Jadi, ketuntasan belajarnya sudah mencapai $80 \%$ atau di atas $75 \%$ dengan rata-rata nilai 7,9.

Dari analisis data hasil penelitian siklus II di atas terlihat bahwa hasil belajar untuk ranah kognitif, afektif dan psikomotor mengalami peningkatan dari siklus I dan sudah mencapai ketuntasan, baik yang ditetapkan dalam BSNP maupun sekolah terteliti. Melalui penelitian ini dibuktikan bahwa penggunaan media dalam pembelajaran dapat meningkatkan hasil belajar peserta didik atau mencapai sasaran yang diinginkan (nilai ketuntasan ideal yang ditetapkan dalam BSNP, yaitu $75 \%$ ).

Berikut ini peneliti sajikan grafik perbandingan nilai rata-rata dan ketuntasan hasil belajar siswa siklus I dan siklus II:

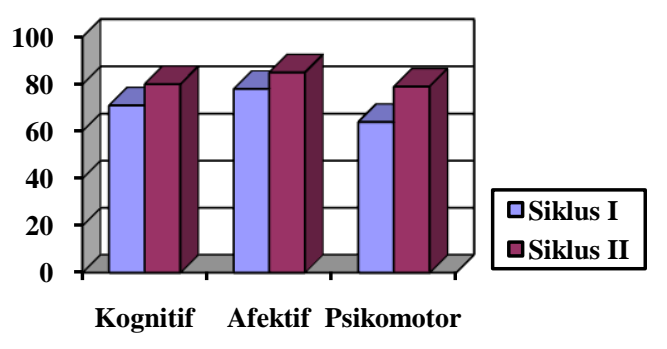

Gambar 1.2

Grafik perbandingan rata-rata hasil belajar

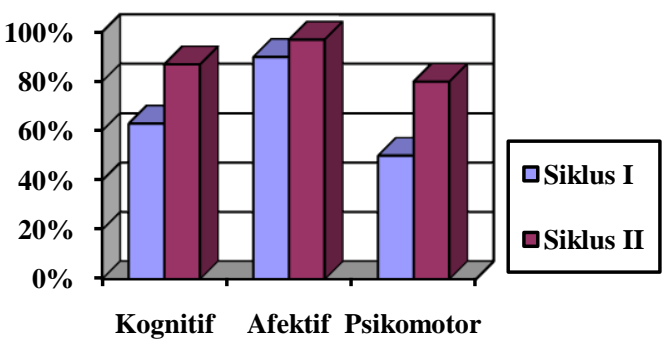

Gambar 1.3

Grafik perbandingan ketuntasan hasil belajar

\section{SIMPULAN DAN SARAN Simpulan}

Dari paparan dan hasil penelitian dan pembahasan dalam Bab IV, simpulan yang dapat diambil dari penelitian ini adalah sebagai berikut:

1. Rencana pelaksanaan pembelajaran PKn dengan menggunakan media audio visual disusun dalam bentuk Rencana Pelaksanaan Pembelajaran (RPP) yang disesuaikan dengan kurikulum. Rancangan pembelajaran ini disusun berdasarkan tahap-tahap penggunaan media audio visual dalam pembelajaran PKn yang terdiri dari tiga tahapan, yaitu: a) Tahap persiapan, b) tahap pelaksanaan/penyajian dan c) tahap tindak lanjut.

2. Pelaksanaan pembelajaran PKn dengan menggunakan media audio visual dapat dilakukan melalui beberapa tahap, yaitu tahap persiapan yang meliputi: mempelajari, menyiapkan, dan memastikan alat/media dapat berfungsi dengan baik; menyampaikan tujuan pembelajaran; membangkitkan skemata peserta didik; kemudian mengkondisikan peserta didik untuk mengamati film dokumenter. Tahap pelaksanaan/penyajian meliputi: peserta dididk diarahkan mengamati film sambil mencatat materi yang penting dari film; tanya jawab tentang film; peserta didik diminta menceritakan film; kemudian guru menjelaskan materi lebih lanjut. Pada tahap tindak lanjut, kegiatan peserta didik diarahkan utuk berdiskusi kelompok tentang film; melaporkan hasil diskusi yang ditanggapi kelompok lain; bermain peran dan mendiskusikannya dilanjutkan dengan 
melaporkan hasil diskusi yang ditanggapi kelompok lain; kemudian dilanjutkan dengan menyimpulkan pelajaran dan evaluasi/penilaian dengan memberikan tes akhir pada peserta didik.

3. Hasil penelitian menunjukkan adanya peningkatan hasil belajar peserta didik dalam pembelajaran PKn dengan menggunakan media audio visual di kelas IV SDN 016 Bangkinang Kota. Pada siklus I diperoleh rata-rata kelas 7,1 untuk ranah kognitif, 7,8 untuk ranah afektif dan 6,4 untuk ranah psiomotor. Rata-rata kelas pada siklus II meningkat menjadi 8,0 untuk ranah kognitif, 8,5 untuk ranah afektif dan 7,9 untuk ranah psikomotor.

\section{Saran}

Berdasarkan simpulan di atas maka peneliti menyarankan hal-hal sebagai berikut:

1. Pembelajaran PKn dengan menggunakan media audio visual layak dipertimbangkan oleh guru untuk menjadi pembelajaran alternatif yang dapat digunakan sebagai referensi dalam memilih media pembelajaran.

2. Bagi peneliti yang ingin menerapkan bentuk pembelajaran ini, dapat melakukan penelitian serupa dengan materi yang lain.

3. Bagi guru-guru yang ingin menerapkan media audio visual, disarankan memperhatikan hal-hal sebagai berikut:

a. Agar lebih kreatif dalam merancang pembelajaran yang sesuai dengan situasi dunianya.

b. Perlu memberikan perhatian, bimbingan dan motivasi belajar secara sungguh-sungguh kepada siswa yang berkemampuan kurang dan pasif, karena siswa yang demikian sering mengantungkan diri pada temannya.

4. Sekolah hendaknya dapat melengkapi sarana dan prasarananya dengan TV dan VCD, karena dengan adanya TV dan VCD tersebut, dapat menunjang motivasi dan hasil belajar siswa.

\section{DAFTAR PUSTAKA}

Arikunto, Suharsimi. dkk. 2007. Penelitian Tindakan Kelas. Jakarta: PT Bumi Aksara.

Arsyad, Azhar. 2006. Media Pembelajaran. Jakarta: Raja Grafindo Persada.

BSNP. 2006. Panduan Penyusunan Kurikulum Tingkat Satuan Pendidikan Jenjang Pendidikan Dasar dan Menengah. Jakarta: Depdiknas.

Cogan, J.J. 1999. Citizenship for The 21 Century: An International Perspective on Education. London: Cogan Page.

Depdiknas. 2006. Kurikulum Tingkat Satuan Pendidikan. Jakarta: Depdiknas.

Djahiri, H.A.K. 2006. Esensi Pendidikan Nilai Moral dan PKn di Era Globalisasi. Dalam Budimansyah dan S. Syam (ed). Pendidikan Nilai dalam Dimensi Pendidikan Kewarganegaraan. Bandung: Lab. PKn FPIPS UPI.

Dimyati dan Mudjiono. 2006. Belajar dan Pembelajaran. Jakarta: Rineka Cipta.

Hamalik, Oemar. 2008. Perencanaan Pengajaran Berdasarkan Pendekatan Sistem. Bandung: Bumi Aksara.

Karim, Muchtar A. dkk. 1996/1997. Pendidikan Matematika I. Jakarta: Depdikbud.

Mulyasana, D. 2006. Manusia dan Pendidikan Kewarganegaraan dalam Perspektif Perubahan. Pendidikan Nilai dan Moral dalam Dimensi Pendidikan Kewarganegaraan (menyambut 70 tahun Prof. Drs. H.A Kosasih Djahiri). Bandung: Lab. PKn FPIPS UPI.

Purwanto, Ngalim. 2006. Prinsip-Prinsip dan Teknik Evaluasi Pengajaran. Bandung: PT. Remaja Rosdakarya Offset.

Somantri, N. 2001. Menggagas Pembaharuan Pendidikan IPS. Bandung: PT. Remaja Rosda Karya.

Sumiati dan Asra. 2007. Metode Pembelajaran Pendekatan Individual. Bandung: Wacana Prima.

Undang-Undang Republik Indonesia Nomor 20 Tahun 2003 tentang Sistem Pendidikan Nasional. 
Wahab, Abdul Aziz. 1997. Pendidikan Pancasila dan Kewarganegaraan (PPKn). Jakarta: Depdikbud.

Wardhani, I.G.A.K. dkk. 2007. Penelitian Tindakan Kelas. Jakarta: Universitas Terbuka.

Wiriaatmadja, Rochiati. 2008. Metode Penelitian Tindakan Kelas untuk Meningkatkan Kinerja Guru dan Dosen. Bandung: PT. Remaja Rosdakarya.

Wibawa, Basuki dan Farida Mukti. 1992. Media Pengajaran. Jakarta: Depdikbud. 